\title{
Seismic source study of the 1989, October 29, Chenoua (Algeria) earthquake from aftershocks, broad-band and strong ground motion records
}

\author{
Abdallah Bounif $\left({ }^{1}\right)\left({ }^{4}\right)$, Mourad Bezzeghoud $\left({ }^{1}\right)\left({ }^{5}\right)$, Louis Dorbath $\left({ }^{2}\right)\left({ }^{6}\right)$, Denis Legrand $\left({ }^{2}\right)$, \\ Anne Deschamps $\left({ }^{3}\right)$, Luis Rivera $\left({ }^{2}\right)$ and Hadj Benhallou $\left({ }^{1}\right)$ \\ (1) CRAAG, Département ESS, Bouzaréah, Algiers, Algeria \\ ( $\left.{ }^{2}\right)$ IPGS, UMR 7516, Strasbourg, France \\ (3) Geosciences Azur, Sophia Antipolis, Valbonne, France \\ $\left(^{4}\right)$ USTHB, Institut des Sciences de la Terre, Algiers, Algeria \\ $\left({ }^{5}\right)$ Universidade de Évora, Departamento de Física, Colégio Luis Verney, Évora, Portugal
}

${ }^{6}$ ) IRD, Paris, France

\begin{abstract}
The broad-band teleseismics records of the earthquake of October 29,1989 in Algeria $\left(M_{W}=6.0\right)$ allow a detailed study of the rupture process of this earthquake. The focal mechanism obtained by $P$ and $S H$ modeling corresponds to reverse faulting with a small amount of left-lateral movement along a fault striking $246^{\circ}$ and dipping $56^{\circ}$. The rupture is found to be complex with two sub-events separated in time but occurring on the same plane. The lowfrequency records of an accelerometer located some $25 \mathrm{~km}$ to the west of the main shock are also better fitted when the rupture is composed of a double pulse. In the two cases, there is strong evidence for the rupture to propagate from south-west towards north-east.The relocalisation of the main shock by using a master-event technique and the data from Italian and Spanish stations led to the same conclusions. Soon after the main event, a temporary seimic network was installed in the epicentral area. The aftershock clouds define a SW-NE fault dipping to the NW compatible with the results of the modelisations of the teleseismic body-waves and the accelerogram. The focal mechanisms correspond mainly to reverse faulting. The maximum principal direction of the stress tensor obtained from the inversion is about N-S and the minimum is vertical, typical of a compressive regime. The Chenoua earthquake took place on a fault which was not recognized as active. Repeated comparable seismic events on this fault and on the fault that borders the massif to the south explain this intriguing topographic feature.
\end{abstract}

Key words North Africa-seismicity - earthquake

\section{Introduction}

The Chenoua earthquake of October 29, 1989 is the third earthquake during the decade 1980-

Mailing address: Dr. Louis Dorbath, IPGS, UMR 7516, 5 rue René Descartes, 67084 Strasbourg cedex, France; e-mail: louis@sismo.u-strasbg.fr
1990 that caused extensive damage and human losses in Algeria, after the El-Asnam earthquake of October 10, 1980 and the Constantine earthquake of October 27, 1985.

Among these three earthquakes, the ElAsnam earthquake is by far the most important in magnitude, $M_{S}=7.3$, as well by the amount of destructions. The El-Asnam earthquake has been extensively studied and is one of the best-known earthquakes in the Mediterranean area (Ouyed et al., 1981; Deschamps et al., 1982; Cisternas et al., 1982; Ruegg et al., 1982; Philip and 
Meghraoui, 1983; Ouyed et al., 1983; Meghraoui et al., 1986; Yielding et al., 1989; Dewey, 1991; Avouac et al., 1992; Bezzeghoud et al., 1995). Surface breaks, with offsets reaching several meters (the maximum displacement was $6 \mathrm{~m}$ ) were observed and mapped along a discontinuous fault more than $35 \mathrm{~km}$ long. The main fault is a thrust due to the regional compressional tectonic stresses, but secondary faults were also activated, mostly on the surface of the hanging wall, presenting any possible situation: strike-slip faulting, inverse faulting and also normal faulting associated with flexures. The modelisation of $P$-wave seismograms indicates a complex source consisting of three segments, following closely the primary surface breaks. The point source focal mechanism corresponds to a thrust fault along a plane striking $225^{\circ} \mathrm{N}$ and dipping $54^{\circ}$. This mechanism is in agreement with the general $340^{\circ} \mathrm{N}$ direction of the compression between Africa and Europe deduced from plate tectonic models (Chase, 1978; Anderson and Jackson, 1987).

The Constantine earthquake, $M_{s}=6.0$, is the most important seismic event in Northeastern Algeria since 1947. The focal mechanism, obtained by modelisation of $P$ and $S H$ waves corresponds to a strike-slip motion along a fault striking $217^{\circ} \mathrm{N}$ and dipping $84^{\circ}$ (Deschamps et al., 1991). The spatial distribution of the aftershocks reveals a complex source divided into three segments(Bounif et al., 1987; Bounif and Dorbath, 1998). Surface breaks were observed, affecting Quaternary deposits. The main segment of breaks was about $4 \mathrm{~km}$ long and mostly formed of left-lateral en échelon cracks. The vertical movements did not exceed $4 \mathrm{~cm}$, while the horizontal ones reached $10 \mathrm{~cm}$. Although the strikes of the faults involved during the ElAsnam and Constantine earthquakes are close to each other and the horizontal compressive stress has about the same directions in the two regions, the two mechanisms are quite different. Deschamps et al. (1991) propose that the motion between Africa and Europe is accomodated by a uniform deformation along an EW direction. In term of stresses, the shape of the stress tensor is changed between the western part and the eastern part of Algeria in such a way that the minimum stress passes from vertical to horizontal (Bounif et al., 1987) and, consequently, the stress regime changes from compression to strike-slip (Armijo et al.,1982).

The Chenoua earthquake of October 28, 1989 , with a magnitude $M_{W}=6.0$, is the largest earthquake instrumentally recorded in the coastal region of Central Algeria. In recent history, the region of Cherchell-Tipaza experienced some moderate to strong earthquakes, whose epicenters are difficult to locate accurately on the basis of macroseismic observations. In any case, in the catalogs of Rothé (1950) and Ambrasseys and Vogt (1988) two earthquakes have their epicenters close to that of the 1989 event and might be comparable in size: the earthquake of March $17,1756\left(36^{\circ} 30^{\prime} \mathrm{N}, 2^{\circ} 32^{\prime} \mathrm{E}\right)$, with a maximum intensity VII MKS in the city of Hadjout and the earthquake of June 18, $1847\left(36^{\circ} 33^{\prime} \mathrm{N}, 2^{\circ} 32^{\prime}\right.$ E), with a maximum intensity VII MKS along the coast of the Chenoua region. The epicenter of the great earthquake of February 03, 1716, which caused extensive destruction in Algiers, is definitively located eastwards (Ambrasseys and Vogt, 1988).

The most important damage caused by the Chenoua earthquake to human settlements was reported on the southeastern side of the Chenoua mountain, in Nador (fig. 1) and around SidiMoussa (close to station SMS, fig. 6) where most of the old houses and buildings were almost completely destroyed. In this area, the intensity should have reached VIII MKS. Tipaza, Cherchell and Hadjout, the main towns of the region, suffered severe shaking, but only a few buildings collapsed (Yelles-Chaouche, 1991). In Algiers, $70 \mathrm{~km}$ eastwards, the earthquake was strongly felt but no severe damage was reported. Landslides and rockfalls were abundant all around the Chenoua mountain, particularly along its eastern and northern flanks, where the coastal road from Tipaza to Cherchell was cut in several points (Meghraoui, 1992).

\section{Geological and tectonic setting}

The coastal range of NW Algeria, the Tellian Atlas, is an active fold and thrust belt which is part of the boundary between Africa and Eurasia. The deformation within the range results from the 


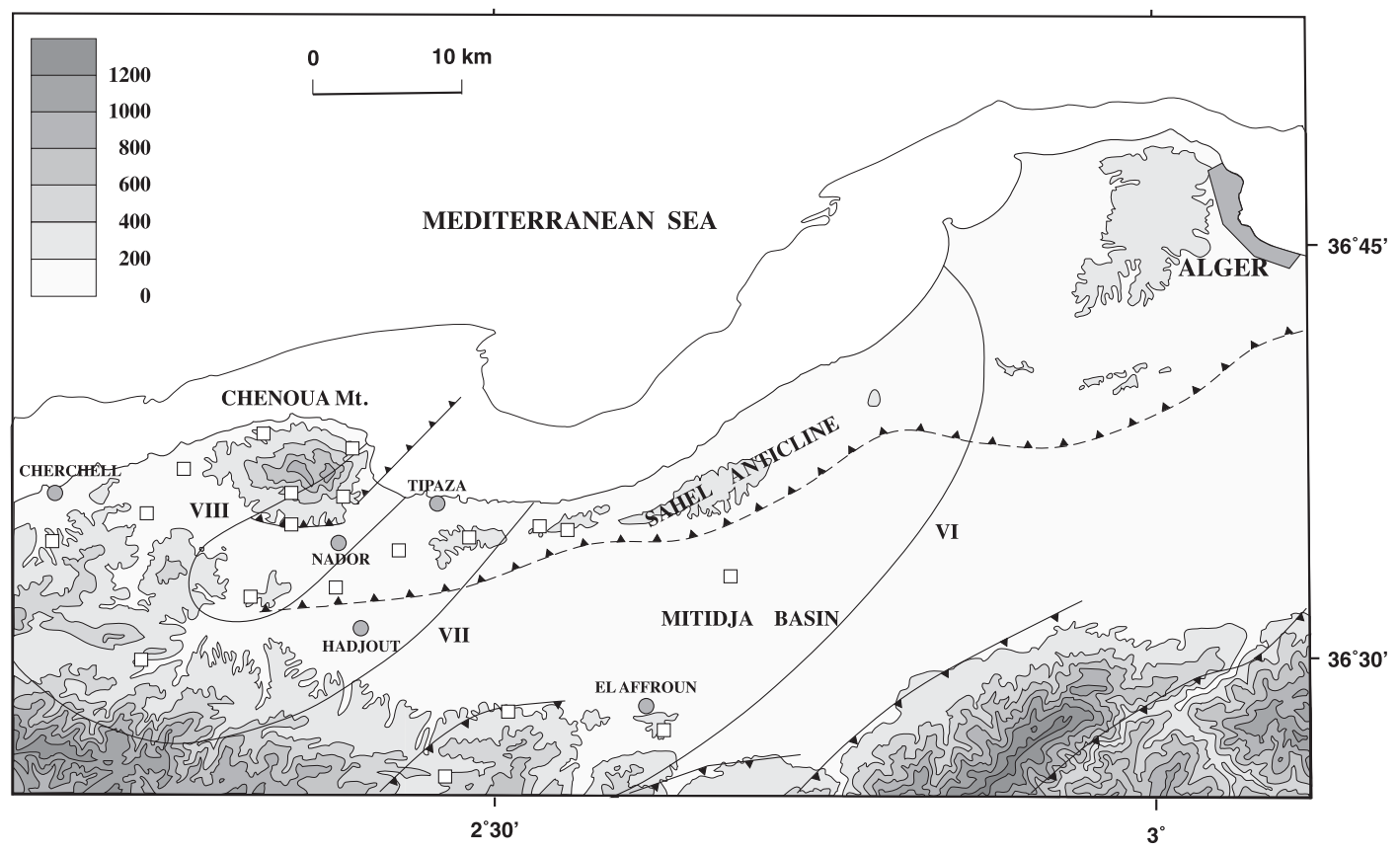

Fig. 1. Topographical and tectonical features of the region of the Chenoua earthquake. Isobath $200 \mathrm{~m}$ is shown. Main faults from Meghraoui (1988). Isoseist lines from Yelles-Chaouche (1991). Open squares: seismological stations.

convergence of the two plates and mostly occurs along reverse faults dipping $40^{\circ}-60^{\circ}$ to the NW (Meghraoui, 1988; Yielding et al., 1989). The general direction of the structures is ENE-WSW, but several major faults are oblique to this trend and often organized in en échelon systems. The El-Asnam fault, for example, strikes SW-NE along its southwestern and central segments, while its northeastern segment trends WSWENE.

The region of Tipaza where the 1989 earthquake occurred is part of the Tellian Atlas range, but presents some specific features, namely the Sahel anticline, the Mitidja basin and the Chenoua massif (fig. 1). The Sahel anticline is a long $(70 \mathrm{~km})$ and narrow (5 $\mathrm{km}$ ) band of hills which runs from Tipaza to Algiers along the sea. Its mean height is about $200 \mathrm{~m}$. It is divided into three $20-30 \mathrm{~km}$ long segments and constitutes an active fold structure (Meghraoui, 1988). According to Meghraoui
(1988), this fold is bordered to the south by a blind thrust fault dipping to the north, divided into three segments as well. However, only the westernmost segment of this conjectural fault is widely held: it extends along the southern flank of the Chenoua mountain where it is exposed and divided, at least near the surface, into two EW parallel branches (Meghraoui, 1988; Belhai et al., 1990). In spite of its moderate height, the Sahel anticline rises above the Mitidja basin that lies at an altitude lower than $100 \mathrm{~m}$. The basin, whose maximum width is about $20 \mathrm{~km}$, is filled with Quaternary deposits and borderered to the south by the high Blida range from which it is separated by an en échelon system of reverse faults dipping to the south. The Mitidja basin narrows toward the west, and disappears just in the vicinity of the Chenoua massif. Westward, the morphology of the coastal region changes and there is no longer a basin between the high range and the coast. However a basin exists, but 
about $30 \mathrm{~km}$ inland: the Cheliff basin, where the El-Asnam earthquake occurred.

The Chenoua mountain is an isolated structure that appears as a peninsula. It culminates at more than $900 \mathrm{~m}$ and has long been an intriguing feature (Glangeaud, 1932). Its northern flank is mostly formed of Paleozoic or even older rocks, while on the southern flank Mesozoic and Tertiary units are dominant. Since Miocene time, N-S compression has prevailed and, consequently, the formation of the massif was thought to be the result of southward thrusting along the nearly E-W faults which border it to the south (Belhai et al., 1990). However, other structures were reported, particularly NW-SE dextral faults and SW-NE left-lateral faults, among which the main one is mapped from Nador to the sea. These faults, and particularly the last one, have been interpreted as transcurrent faults which accomodate the motion of the massif towards the south (Belhai et al., 1990). However, the steep topography of the eastern flank of the massif, the linearity of the contour lines and the fold drawn by the isobaths are strong evidence of dip slip motion (fig. 1 and fig. 6).

\section{Main shock mechanism}

Available digital records of $P$ and $S H$ body waves from the global networks (IRIS, GDSN and GEOSCOPE), with epicentral distances in the range $30^{\circ}-85^{\circ}$, have been collected to perform a global inversion of seismic moment, slip geometrical parameters, and source duration. We used the version of McCaffrey and Abbers (1988) of the inversion procedure of Nabelek (1984). This procedure is based on the minimization, in the least square sense, of the misfit between observed and synthetic seismograms. Synthetic seismograms were computed in a homogeneous half-space and included $P$ (respectively $S H$ ), $p P$ and $s P$ (respectively $s S H$ ) phases. $Q$-factor was defined with attenuation time constants of $t^{*}=1 \mathrm{~s}$ and $t^{*}=4 \mathrm{~s}$ for $P$ and $S H$ waves respectively. The synthetic seismogram at each station is obtained by convolution of Green's function of the propagation with the instrumental response and then by the source time function. The latter is described by a fixed number of overlapping elementary isosceles triangles of the same duration. Due to the non-even azimuthal distribution

Table I. List of the stations used in the inversion procedure steps I. $\Delta$ and $\Phi$ are, respectively, epicentral distance and azimuth of the station.

\begin{tabular}{|c|c|c|c|c|c|c|}
\hline Station & $\Delta\left(^{\circ}\right)$ & $\Phi\left(^{\circ}\right)$ & $\begin{array}{c}\text { Weight } \\
\text { LP P }\end{array}$ & $\begin{array}{l}\text { Weight } \\
\text { LP SH }\end{array}$ & $\begin{array}{l}\text { Weight } \\
\text { BRB P }\end{array}$ & $\begin{array}{c}\text { Weight } \\
\text { BRB SH }\end{array}$ \\
\hline OBN/IRIS & 29.6 & 40.8 & & & 0.4 & 0.4 \\
\hline KEV/IRIS & 35.6 & 14.4 & 0.7 & 0.6 & & 0.6 \\
\hline ARU/IRIS & 41.9 & 43.7 & & & 0.3 & 0.4 \\
\hline AGD/GEOSCOPE & 44.1 & 114.2 & & & 1 & \\
\hline WMQ/GDSN & 62.7 & 54.3 & 0.3 & 0.4 & 0.3 & 0.4 \\
\hline BCAO/IRIS & 35.4 & 151.5 & 0.7 & 1 & & \\
\hline SLR/IRIS & 66.8 & 154.7 & 0.7 & & & \\
\hline SCP/IRIS & 60.8 & 300.8 & 0.9 & 1 & & \\
\hline LON/IRIS & 83 & 325.1 & 0.9 & & & \\
\hline BJI/GDSN & 82.3 & 45.2 & & 0.4 & 0.3 & \\
\hline MBO/GEOSCOPE & 28.2 & 222.9 & 1 & & & \\
\hline HIA/GDSN & 77.9 & 36.5 & 0.4 & 0.4 & 0.4 & \\
\hline LZH/GDSN & 77.2 & 54.5 & 0.3 & 0.4 & 0.3 & \\
\hline KMI/GDSN & 83 & 64 & 0.4 & 0.5 & 0.4 & \\
\hline
\end{tabular}



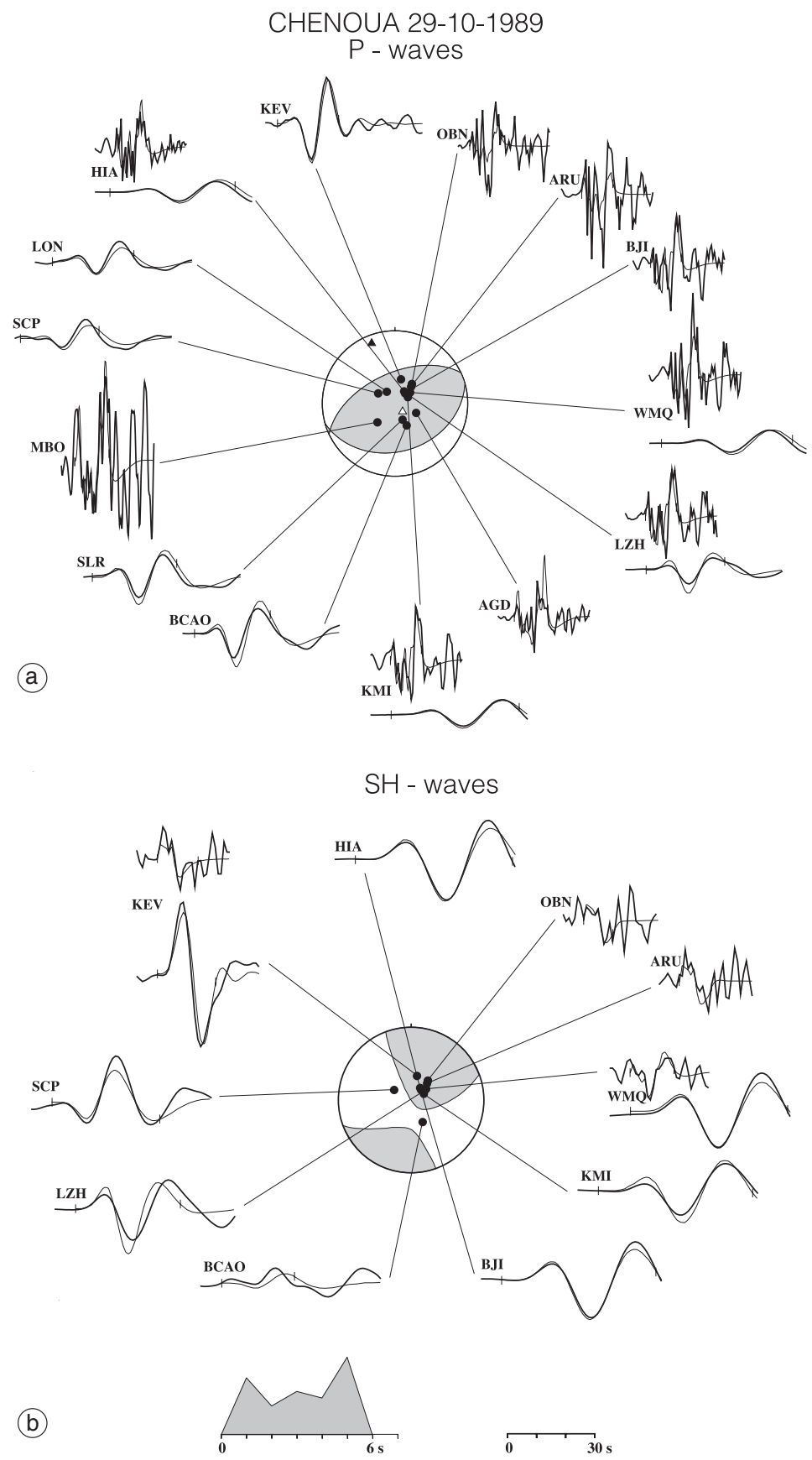

Fig. 2a,b. Comparison between observed and synthetic signals for $P$ (a) and $S H$ (b) waves for a single point source inversion (step I). Thick lines: observed signal; thin lines: synthetic signal. Solid and open triangles: $P$ and $T$ axes, respectively. 
of the available records, weighting factors have been applied to seismograms, as given in table I.

Body waves on Long Period (LP) records have a very simple shape (fig. 2a,b), as could be expected from the moderate magnitude of the event and the characteristic frequency of the channels (around $25 \mathrm{~s}$ ). On the other hand, broadband (BRB) records (fig. 3) suggest that two
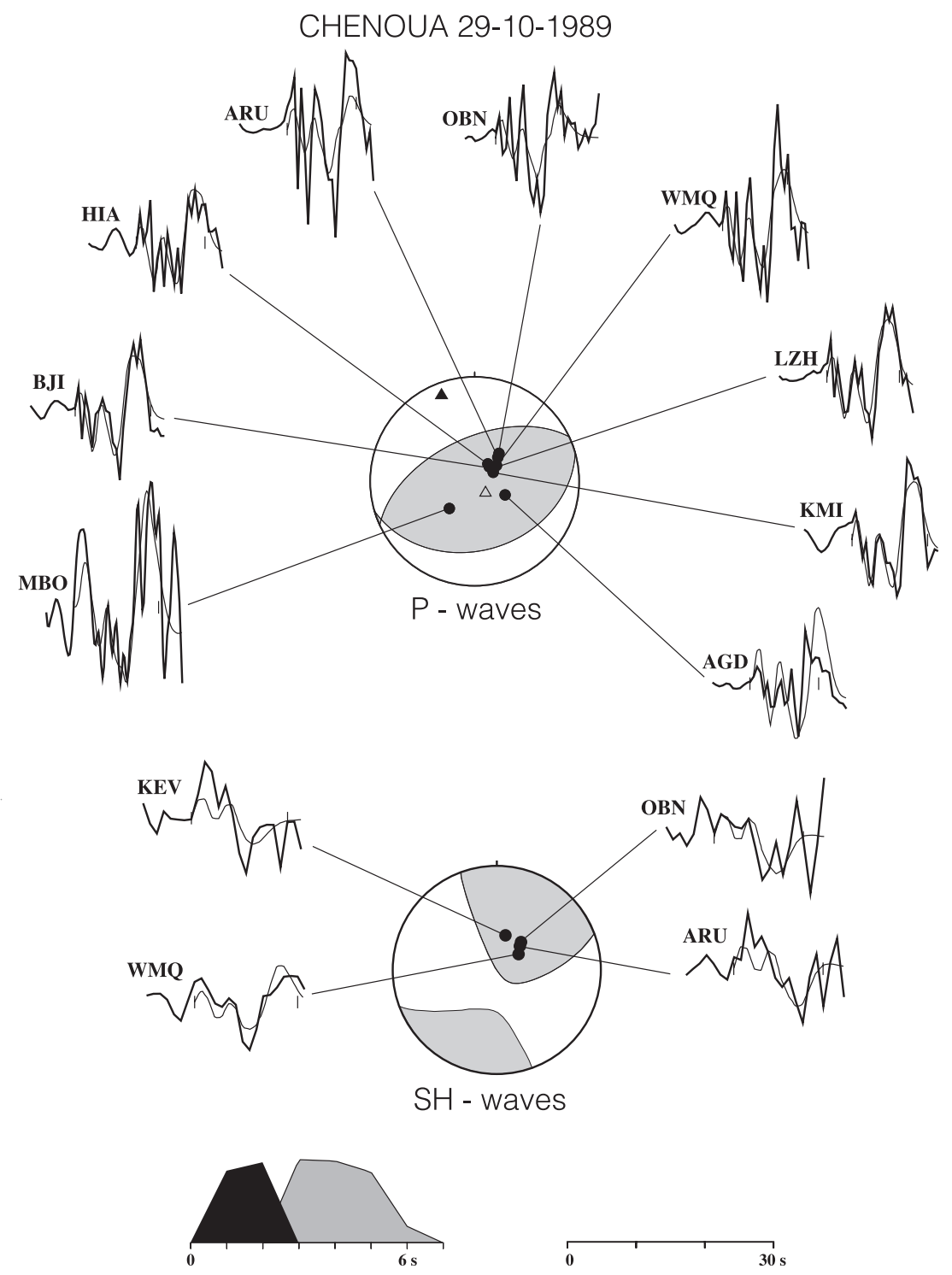

Fig. 3. Comparison between observed BRB and synthetic signals for the final model consisting of two sub-events (step II). Conventions as in fig. 2a,b. 
subevents should be introduced to explain the waveforms complexity. All BRB records present about the same pattern: the $P$ waves signal begins by 2 or 3 high frequency $(0.5 \mathrm{~Hz})$ oscillations followed by a lower frequency phase, 7 to $8 \mathrm{~s}$ after, which is interpreted as the $s P$ phase.

In a first stage, we inverted the complete data set (LP and BRB) with a single point source and a source time function constituted by 5 elementary, 2 s duration, isosceles triangles. The focal solution deduced from this inversion, azimuth $=246^{\circ}$, $\operatorname{dip}=56^{\circ}$, rake $=86^{\circ}$, is in good agreement with the CMT solution, the isoseismal map (fig. 1) and the aftershocks space distribution (figs. 6 and 9). The seismic moment is $8.2 \times 10^{17} \mathrm{Nm}$, also in good agreement with the CMT solution $\left(9.6 \times 10^{17} \mathrm{Nm}\right)$. Due to the frequency content of the data, there is a large trade-off between the focal depth, $11 \mathrm{~km}$, and the source time duration. The long period and BRB waveforms, together with the observed ones, computed for the best solution obtained from the inversion procedure are shown in figs. 2a,b and 3. The low frequency $P$ and $S H$ waves are quite well modelized, with a RMS of 0.12 , and the relative complexity of the source time function may already be noticed.

In a second stage, we used only the BRB records. The initial one point source model was replaced by a two sub-events model, the first one represented by 2 elementary, $2 \mathrm{~s}$ duration, isosceles triangles and the second one by 3 triangles, so that the total source duration is the same as in the first stage. The fault geometry was assumed to be the same throughout the rupture process and the focal mechanisms of the two subevents identical to that obtained in the first stage. These parameters were not changed in the course of the inversion process, nor was the rupture velocity fixed at $2.7 \mathrm{~km} / \mathrm{s}$. The trial depth of each sub-event was $11 \mathrm{~km}$. The second sub-event was initially delayed with respect to the first by $2 \mathrm{~s}$, according to the shape of the time source function obtained at the first step, so that the two events were overlapping in time. Two rupture directions corresponding to the strike of the fault were tested: $66^{\circ} \mathrm{N}$ and $246^{\circ} \mathrm{N}$. Thus the inversion is performed to resolve 9 parameters: the source depth of each sub-event, the amplitudes of the elementary sources, the origin time of the second source relatively to the first one and the distance between the two sources along the direction of rupture propagation. The results are clearly better in the case of a propagation in the direction $66^{\circ} \mathrm{N}$, namely from the continent towards the Mediterranean Sea. With this direction the RMS is about $50 \%$ smaller than in the case of a rupture propagating in the opposite direction. However, this result is constrained by only one station, MBO. The best solution is shown in fig. 3. The first event occurred at a depth of $13 \mathrm{~km}$ and the second one $4 \mathrm{~km}$ to the NE and at a depth of 8 $\mathrm{km}$. These depths, which are better constrained than the depth obtained in the first (single point source) stage, are in fairly good agreement with the vertical extension of the aftershocks area (fig. 6).

The results of the inversion of body waves of the main shock may be summarized as follow (table II): the Chenoua earthquake mechanism is a nearly pure reverse faulting along a plane striking $246^{\circ} \mathrm{N}$ and dipping $56^{\circ}$. The main shock is composed of two sub-events of $3 \mathrm{~s}$ and $4 \mathrm{~s}$ duration respectively, with the same mechanism, and the rupture propagated likely from SW to NE.

A large aftershock $\left(M_{S}=5.4\right)$ followed the main shock by about $10 \mathrm{~min}$. The corresponding $P$ waves have small amplitudes and, moreover, arrive in the coda of the main shock; $S$ waves could not be separated from the noise. On the other hand, the number of available BRB records is small (7) and the azimuthal coverage is poor. Nevertheless, the inversion routine has been attempted to modelize this event with an isosceles triangle of $1.6 \mathrm{~s}$ duration as source time function. We tested many models with different values of strike, dip and rake and selected a «best» solution based on the visual quality of fitting and on the minimum RMS value determined after the first iteration of the inversion process. The parameters of this best solution are $220^{\circ} \pm 20^{\circ}, 55^{\circ} \pm 5^{\circ}$, $25^{\circ} \pm 5^{\circ}, \mathrm{h}=8 \mathrm{~km} \pm 1 \mathrm{~km}$ for the strike, the dip, the rake and the depth respectively (table II). The seismic moment is $M_{0}=2.0 \times 10^{17} \mathrm{Nm}, 4$ times less than for the mains hock. The dip is mostly constrained by the station COL, while the rake is constrained by all the stations with the exception of HIA. Changing the depth by $2 \mathrm{~km}$ produces a noticeable degradation of the fitting of the waveforms. The strike is poorly controlled. The 
Table II. Source parameters of the main shock and the large aftershock for final solutions obtained respectively from inversions I and II and the BRB modeling. (1) and (2) indicate the nodal planes; (a) and (b) correspond to sources time function obtained from inversion II. CMT indicates centroid moment tensor solution. The errors are indicated in brackets.

\begin{tabular}{|c|c|c|c|c|c|c|c|}
\hline & & $\begin{array}{c}\text { Strike } \\
\left({ }^{\circ}\right)\end{array}$ & $\begin{array}{l}\text { Dip } \\
\left({ }^{\circ}\right)\end{array}$ & $\begin{array}{l}\text { Rake } \\
\left({ }^{\circ}\right)\end{array}$ & $\begin{array}{c}\text { Depth } \\
(\mathrm{km})\end{array}$ & $\begin{array}{c}M_{0} \times 1017 \\
(\mathrm{Nm})\end{array}$ & $\begin{array}{l}\text { STF } \\
(\mathrm{s})\end{array}$ \\
\hline \multirow{2}{*}{ CMT } & 1 & 231 & 50 & 62 & \multirow{2}{*}{15} & \multirow[t]{2}{*}{9.6} & \\
\hline & 2 & 91 & 48 & 119 & & & \\
\hline \multirow{2}{*}{ Step I } & 1 & $\begin{array}{l}246 \\
( \pm 4)\end{array}$ & $\begin{array}{c}56 \\
( \pm 2)\end{array}$ & $\begin{array}{c}86 \\
( \pm 4)\end{array}$ & \multirow[b]{2}{*}{$\begin{array}{c}11 \\
( \pm 0.5)\end{array}$} & \multirow[b]{2}{*}{$\begin{array}{c}8.2 \\
( \pm 0.6)\end{array}$} & \multirow[b]{2}{*}{$\begin{array}{c}6.0 \\
( \pm 0.5)\end{array}$} \\
\hline & 2 & $\begin{array}{c}71 \\
( \pm 4)\end{array}$ & $\begin{array}{c}34 \\
( \pm 2)\end{array}$ & $\begin{array}{c}94 \\
( \pm 4)\end{array}$ & & & \\
\hline \multirow[t]{2}{*}{ Step II } & $\mathrm{a}$ & & & & $\begin{array}{c}13 \\
( \pm 2)\end{array}$ & $\begin{array}{c}3.4 \\
( \pm 0.6)\end{array}$ & $\begin{array}{c}3.0 \\
( \pm 0.6)\end{array}$ \\
\hline & $\mathrm{b}$ & & & & $\begin{array}{c}8 \\
( \pm 1)\end{array}$ & $\begin{array}{c}4.5 \\
( \pm 0.9)\end{array}$ & $\begin{array}{c}4.0 \\
( \pm 0.9)\end{array}$ \\
\hline \multirow{2}{*}{$\begin{array}{c}\text { Large } \\
\text { aftershock }\end{array}$} & 1 & $\begin{array}{c}220 \\
( \pm 20)\end{array}$ & $\begin{array}{c}55 \\
( \pm 5)\end{array}$ & $\begin{array}{c}25 \\
( \pm 5)\end{array}$ & \multirow[b]{2}{*}{$\begin{array}{c}8 \\
( \pm 1)\end{array}$} & \multirow[b]{2}{*}{2} & \multirow[b]{2}{*}{1.6} \\
\hline & 2 & $\begin{array}{c}115 \\
( \pm 20)\end{array}$ & $\begin{array}{c}70 \\
( \pm 5)\end{array}$ & $\begin{array}{l}115 \\
( \pm 5)\end{array}$ & & & \\
\hline
\end{tabular}

final solution for this large aftershock is shown in fig. 4. It is a left-lateral strike-slip faulting with a large component of reverse movement. Although this mechanism is poorly constrained by the available records, it is in agreement with the stress tensor deduced from the aftershocks analysis (see below).

\section{Modeling of the acceleration}

A Kinemetrics SMA1 accelerometer was in operation in the city of Cherchell, some $25 \mathrm{~km}$ to the west of the relocated epicenter of the mainshock (see below), that is about 2 times the length of the ruptured zone. This instrument was triggered by the $P$-waves of the main shock, so that the complete $S$-waveform on the three components is available. Using the data from a single station, the contribution of the source cannot be distinguished from that of the propagation and thus fine details of the history of the rupture are outside the scope of this paper. Therefore our purpose is limited to a broad description of the propagation of the rupture, assumed to be of constant velocity, along a fault plane in a homogeneous model, with the aim of strengthening some features which may not convincingly be resolved by the inversion of the body waves. To achieve this purpose, ground velocity, obtained by integration of the digitalized original record, was subsequently filtered through a five pole Butterworth low-pass filter at $0.3 \mathrm{~Hz}$. Therefore, most of the high frequency content which is related to the complexities of the rupture and the medium was eliminated from the original accelerogram.

The theoretical velocity was calculated at the surface of a homogeneous, isotropic and elastic half-space for an extended source by summing the contribution of point-sources regularly distributed on the fault plane every $200 \mathrm{~m}$. The spatial derivatives of the complete (near and far fields) Green's functions were calculated in the time domain using a Cagniard-de Hoop method (Johnson, 1974; Hartzell et al., 1978). We chose 


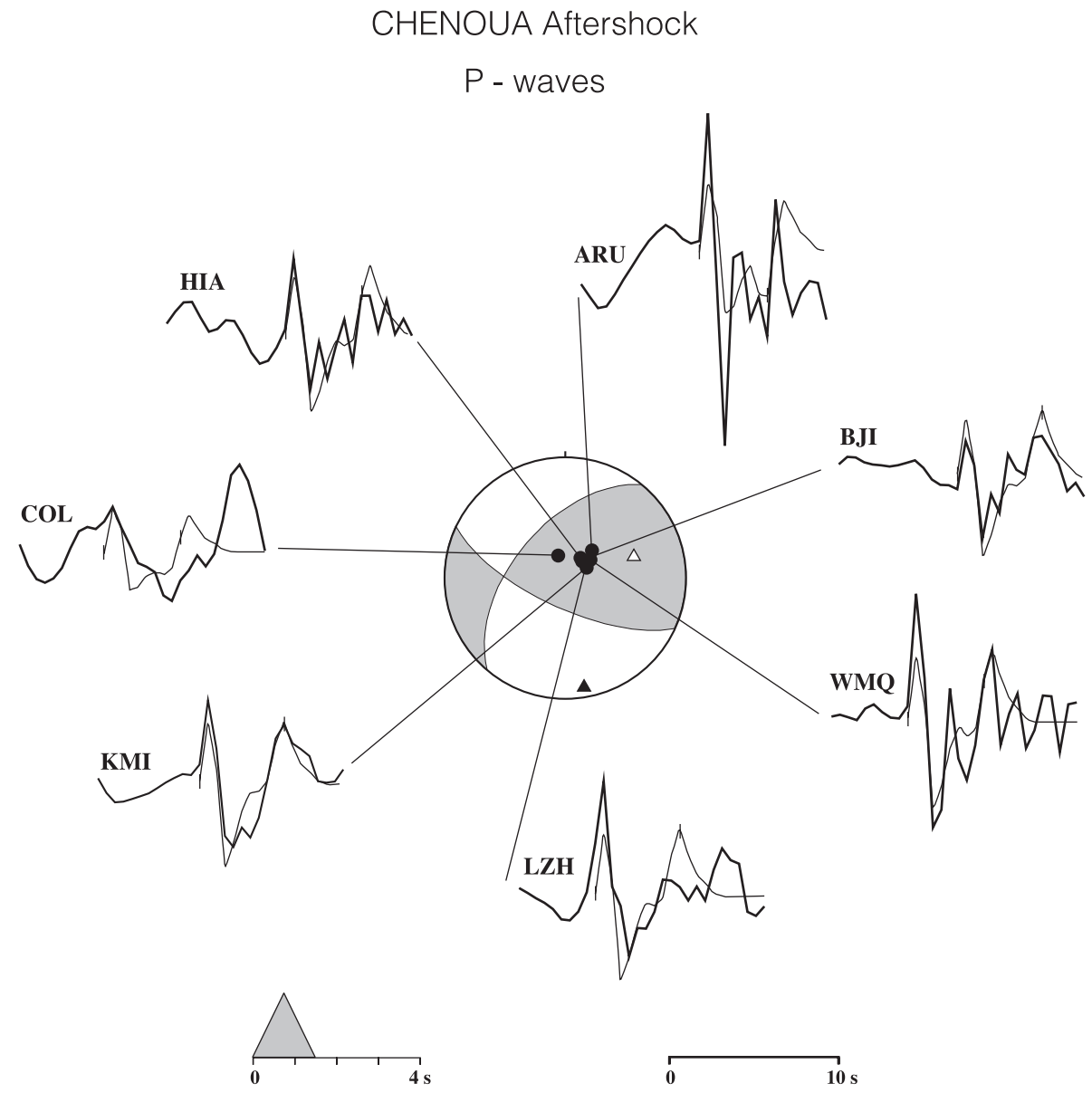

Fig. 4. Comparison between observed BRB and synthetic signals for the large aftershock 10 min after the main shock. Conventions as in fig. 2a,b.

a $P$-wave velocity of $6.0 \mathrm{~km} / \mathrm{s}$, a Poisson's ratio of 0.25 , a rise time of $0.3 \mathrm{~s}$ and a sampling rate of 50 samples/s. The synthetic seismograms were low-pass filtered through the same filter as the data. The rupture initiates at one point of the grid and propagates with a constant velocity of 2.7 $\mathrm{km} / \mathrm{s}$, so that the rupture front is a circle.

The synthetic waveforms were computed for two general models, following closely the way already used in the LP and BRB body-waves inversion: in the first model the main shock consists in a single event, while in the second model two sub-events are involved. In both cases, the geometry and the dimensions of the trial fault-plane were the same and drawn from the body-waves modelling and the aftershocks distribution. The dimensions, $11 \mathrm{~km}$ long and 10 $\mathrm{km}$ wide, were not changed during the modelling process. The modulus of the slip vector is fixed by the seismic moment and the surface of the fault.

In the first model, four parameters are free, the strike and the dip of the fault, the rake and the position of the nucleation point. A trial and error method was followed to adjust these parameters and the first trial faulting mechanism was the 


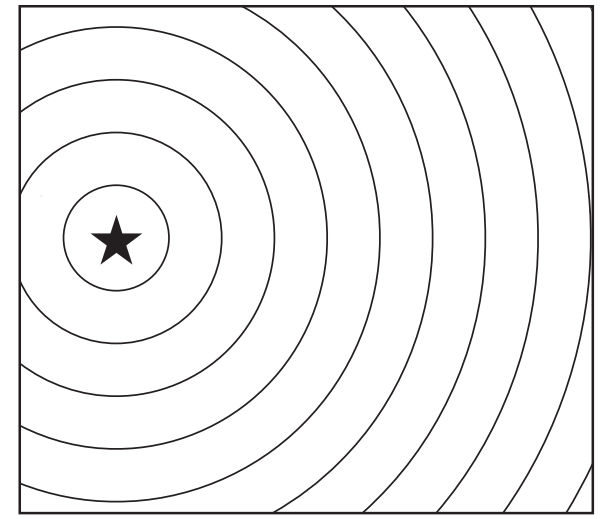

MODEL 1
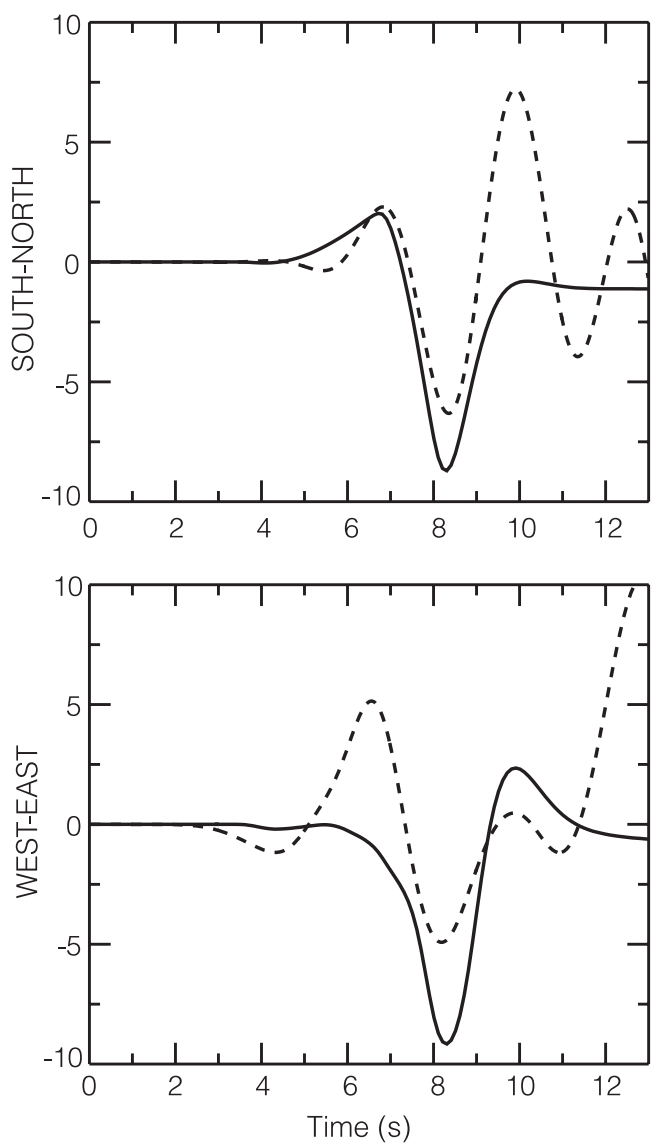

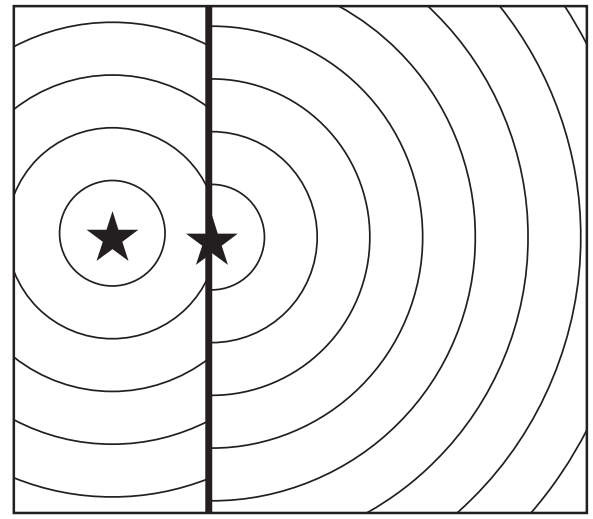

MODEL 2
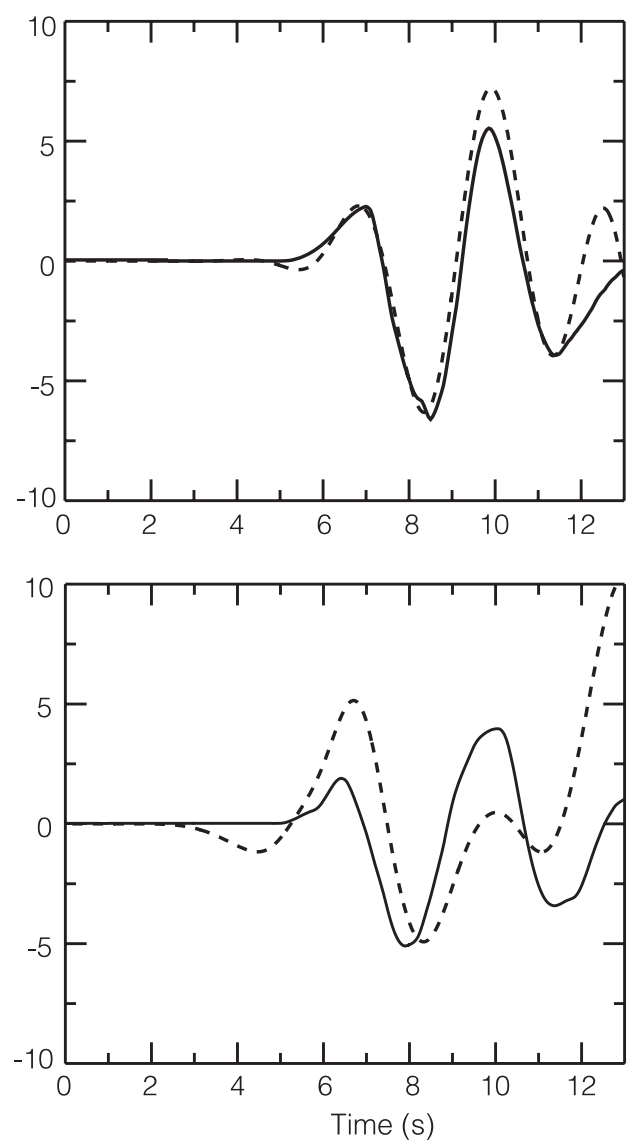

Fig. 5. Rupture models from the inversion of the accelerogramm. Continuous line: observed signal; dashed line: synthetic signal. 
mechanism resulting from the single-event inversion of body-waves. The best visual fit of the synthetic velocity with the observed data is achieved when the strike, dip and rake take the values $230^{\circ}, 55^{\circ}$ and $86^{\circ}$ respectively and the nucleation point is at a distance of $1.5 \mathrm{~km}$ from the southern tip of the fault and at a depth of $3.8 \mathrm{~km}$ (fig. 5). The rupture is therefore bi-directional, but the main part develops towards NE.

The second model consists of the summation of two sub-events, both of which with the same focal mechanism gathered fom the previous single event model. Consequently, the free parameters are now the position of the nucleation point and the length of the first sub-event (the second sub-event initiates where the first stops) and the time lag between the two sub-events. In the best model, the nucleation point is located on the southwestern tip of the fault, at a depth of $3.8 \mathrm{~km}$. It broke $3 \mathrm{~km}$ of the complete length of the fault. The second sub-event occurred $2.0 \mathrm{~s}$ after the first one and broke the remaining $8 \mathrm{~km}$ of the fault plane (fig. 5). Its nucleation point is also at a depth of $3.8 \mathrm{~km}$ but at $3 \mathrm{~km}$ from the southwestern tip of the fault. The two models and the synthetic wave forms of the horizontal components together with the corresponding data are shown on fig. 5. The one-source model explains reasonably well only the first $3 \mathrm{~s}$ of the $\mathrm{N}-\mathrm{S}$ component, and then diverges largely from the data. The two-source model explains a longer part of the data: the position of the main peaks and troughs and their amplitudes are quite well matched for about $8 \mathrm{~s}$, a time corresponding roughly to the source duration.

The direct modeling of the accelerogram leads therefore to results close to those deduced from the inversion of the body waves. Of particular importance are the fact that both methods require a two sub-events source model to match data more accurately and favour a rupture propagation from the continent towards the sea.

\section{Recording and analysis of the aftershocks}

One day after the main shock, 8 smoked paper recording seismographs (Sprengnether MEQ 800), equipped with $1 \mathrm{~Hz}$ vertical sensors (Mark Product L4C), were installed in the epicentral zone by the CRAAG. A few days later, this network was complemented by 8 identical instruments and 4 three components digital recorders from the IPG of Strasbourg, the latter equipped with $2 \mathrm{~Hz}$ seismometers (Mark Product L22). The three component digital recorders were installed in sites where smoked paper recorders were already working, so that for aftershocks location and determination of focal solution purposes, which involve only arrival times and polarities, the network was composed of 16 stations (fig. 1 and table III). This network was operated from November 07 to November 18. After this period, the IPG Strasbourg instruments were removed, but the CRAAG network was maintained up to January 06, 1990.

The analogic instruments functioned at 60 $\mathrm{mm} / \mathrm{mn}$ and internal time marks were placed at the second, allowing a time reading precision of $0.05 \mathrm{~s}$ for $P$ waves. The drifts of the internal clocks were measured by checking every two

Table III. List of the temporary stations installed to monitor the aftershocks activity.

\begin{tabular}{cccc}
\hline \hline Sta & Lat $(\mathrm{N})$ & Lon $(\mathrm{E})$ & Alt $(\mathrm{m})$ \\
\hline AEK & $36^{\circ} 34.44^{\prime}$ & $2^{\circ} 32.20^{\prime}$ & 152 \\
BAR & $36^{\circ} 31.79^{\prime}$ & $2^{\circ} 18.87^{\prime}$ & 192 \\
CAI & $36^{\circ} 33.95^{\prime}$ & $2^{\circ} 10.16^{\prime}$ & 168 \\
CAL & $36^{\circ} 35.68^{\prime}$ & $2^{\circ} 20.73^{\prime}$ & 490 \\
CRB & $36^{\circ} 37.52^{\prime}$ & $2^{\circ} 23.64^{\prime}$ & 176 \\
FIG & $36^{\circ} 32.30^{\prime}$ & $2^{\circ} 22.78^{\prime}$ & 92 \\
KAR & $36^{\circ} 36.53^{\prime}$ & $2^{\circ} 15.83^{\prime}$ & 168 \\
MOU & $36^{\circ} 35.49^{\prime}$ & $2^{\circ} 23.33^{\prime}$ & 230 \\
ATB & $36^{\circ} 32.72^{\prime}$ & $2^{\circ} 40.79^{\prime}$ & 45 \\
BDL & $36^{\circ} 33.60^{\prime}$ & $2^{\circ} 25.73^{\prime}$ & 120 \\
BHN & $36^{\circ} 27.27^{\prime}$ & $2^{\circ} 22.23^{\prime}$ & 260 \\
CHN & $36^{\circ} 37.97^{\prime}$ & $2^{\circ} 19.71^{\prime}$ & 220 \\
DJR & $36^{\circ} 25.07^{\prime}$ & $2^{\circ} 32.45^{\prime}$ & 460 \\
HAM & $36^{\circ} 34.74^{\prime}$ & $2^{\circ} 14.23^{\prime}$ & 60 \\
MCR & $36^{\circ} 29.37^{\prime}$ & $2^{\circ} 13.92^{\prime}$ & 280 \\
SDR & $36^{\circ} 34.46^{\prime}$ & $2^{\circ} 33.82^{\prime}$ & 260 \\
SHL & $36^{\circ} 27.83^{\prime}$ & $2^{\circ} 30.73^{\prime}$ & 220 \\
SMS & $36^{\circ} 34.51^{\prime}$ & $2^{\circ} 20.53^{\prime}$ & 220 \\
TPZ & $36^{\circ} 34.01^{\prime}$ & $2^{\circ} 28.72^{\prime}$ & 240 \\
\hline
\end{tabular}


days the internal time against the reference time radio-transmitted by DCF and by the Omega system. For most of the stations, the drifts were lower than $0.1 \mathrm{~s}$ per day. Time signals for the digital equipment were obtained from the Omega system.

The present section deals with the results obtained from the data collected during the period from November 07 to November 18, when the complete network was in operation. Several hundreds of aftershocks were recorded during this period. To insure a good quality to the locations we kept only the events with at least nine $P$-wave and two $S$-wave arrival-times.

No detailed deep seismic sounding was performed in the region and, consequently, the velocity structure is poorly known. Thus we used about 50 well-recorded aftershocks, with more than $12 P$-wave and more than $2 S$-wave arrivaltimes, to improve the velocity model to be used in the location process. First, we located them using the five velocity models already proposed by Ouyed (1981) for the El-Asnam region. It resulted that the model labelled 5 by Ouyed was the best one, yielding the smallest mean RMS. It consists of a $2 \mathrm{~km}$ thick layer with a $4.5 \mathrm{~km} / \mathrm{s}$ $P$-wave velocity over a half-space with a 5.5 $\mathrm{km} / \mathrm{s} P$-wave velocity. Then we changed the thickness of the upper layer and/or the $P$-wave velocities in the two layers. Several trials led to the final velocity structure consisting of a 3 $\mathrm{km}$ thick upper layer with a $4.5 \mathrm{~km} / \mathrm{s} P$-wave velocity over a $9 \mathrm{~km}$ thick layer with a $5.5 \mathrm{~km} / \mathrm{s}$ $P$-wave velocity and a half-space with a $6.5 \mathrm{~km} / \mathrm{s}$ $P$-wave velocity. The insertion of the second discontinuity is not absolutely required, it has only a very weak influence on the mean RMS value, but improves the residuals for the largest epicentral distances. The influence of the $V_{p} / V_{s}$ ratio has been found to be weak on the mean RMS whatever the velocity model tested, and thus a $V_{p} / V_{s}$ ratio of 1.73 was adopted.

The aftershocks were located using the HYPOINVERSE program (Klein, 1978) and we selected «good» locations on the basis of the following two criteria: RMS $<0.3 \mathrm{~s}$ and conditioning factor $<100.392$ events fulfil these conditions among which $85 \%$ have RMS lower than $0.2 \mathrm{~s}$. In previous studies (Lyon-Caen et al., 1988; Dorbath et al., 1992, for example) using dense networks that cover the aftershock zones quite well, it has been shown that the epicentral locations are only weakly dependent on the velocity model. Making comparison between the locations of the same events in different velocity structures, they also concluded that the errors given by HYPOINVERSE are realistic estimates of relative location errors of the events. Unfortunately, in the present study, these favourable conditions were not met for the complete set of aftershocks, because a large number of them are not inside the network, since they occurred beneath the Mediterranean Sea.

Besides the criteria already mentioned, a criterion commonly used to select events on the basis of the quality of their location is to exclude the events whose epicentral distance to the nearest station is greater than the focal depth. Nearly one third of the aftershocks we have kept, and which will be presented further on, are in this situation and would be excluded on the basis of this criterion. However, among these events some of them occurred inside the network, at very shallow depths. This is a common situation encountered in studies of local seimicity or aftershocks and, generally, these events are kept because they are actually shallow, even if the computed errors for depth are quite large, and they preserve some spatial homogeneity in the aftershocks distribution pictures. It is with a similar purpose that we kept the events far from the network whose depth is smaller than the epicentral distance to the nearest station. To remove them would lead to a strongly biased picture of the aftershock zone. However, we checked the quality of these locations against that of the events which fulfil the above-mentioned criterion, using the standard errors for depth and epicentral position as a measure of the quality. It is known that these errors underestimate the true errors but they are convenient to our purpose which is only to compare two sets of data. The mean errors for epicentral position are $0.91 \mathrm{~km}$ and $0.75 \mathrm{~km}$ and the mean errors for depth 1.30 $\mathrm{km}$ and $0.76 \mathrm{~km}$ respectively for these two sets of events. It is obvious that the quality is reduced when the aftershocks are far from the network and that the depths are more affected, however not to prevent making use of them, at least to estimate the extension of the aftershock area. 


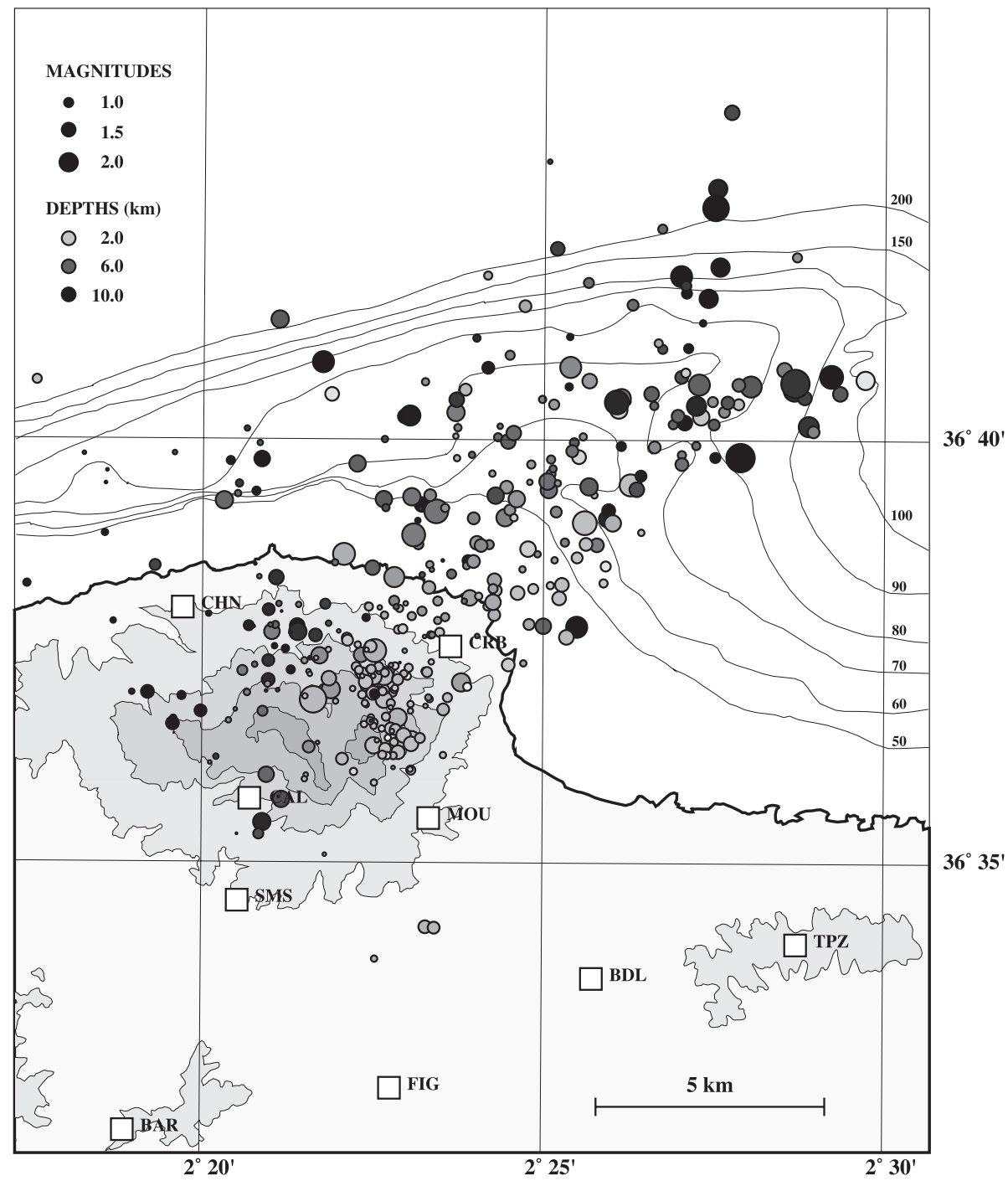

Fig. 6. Map view of the epicenters of the aftershocks. Open squares: seismological stations.

\section{Aftershocks distribution and focal mechanisms}

We present the locations of the selected aftershocks in map view in fig. 6. They depict an elongated area in a general SW-NE direction, about $15 \mathrm{~km}$ in length and $7 \mathrm{~km}$ in width. About $60 \%$ of this area lies under the Mediterranean Sea.
The remaining area covers the Chenoua massif, principally its northeastern flank, only few events occurred beneath its southern flank. Neither on this map, nor on the cross-sections (fig. 7a-c), any segmentation of the aftershock zone appear clearly, as should be expected in the case where the two sub-events found in the course of the inversion of body wave and the modelisation 
(a)

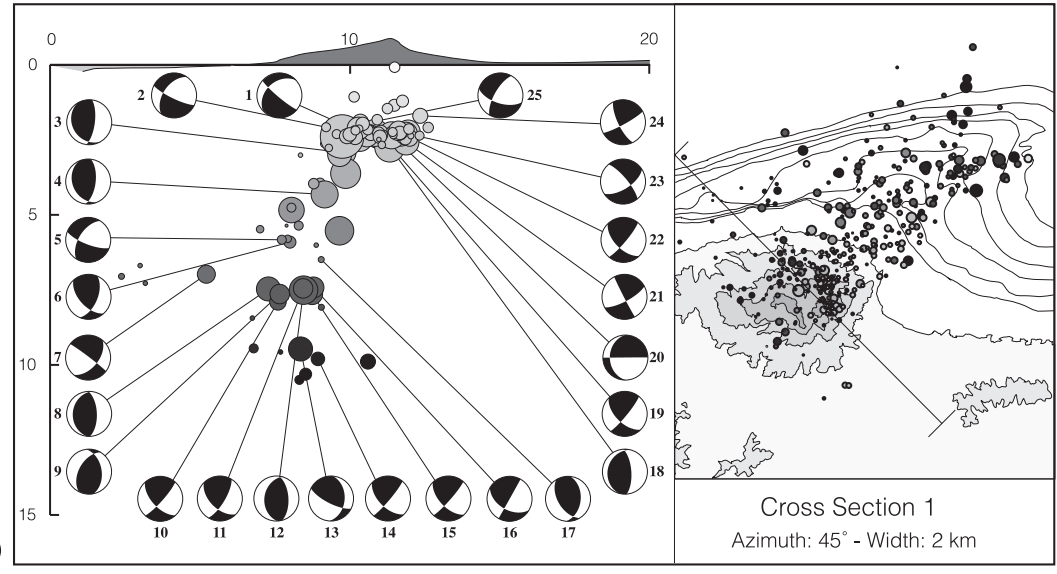

(b)

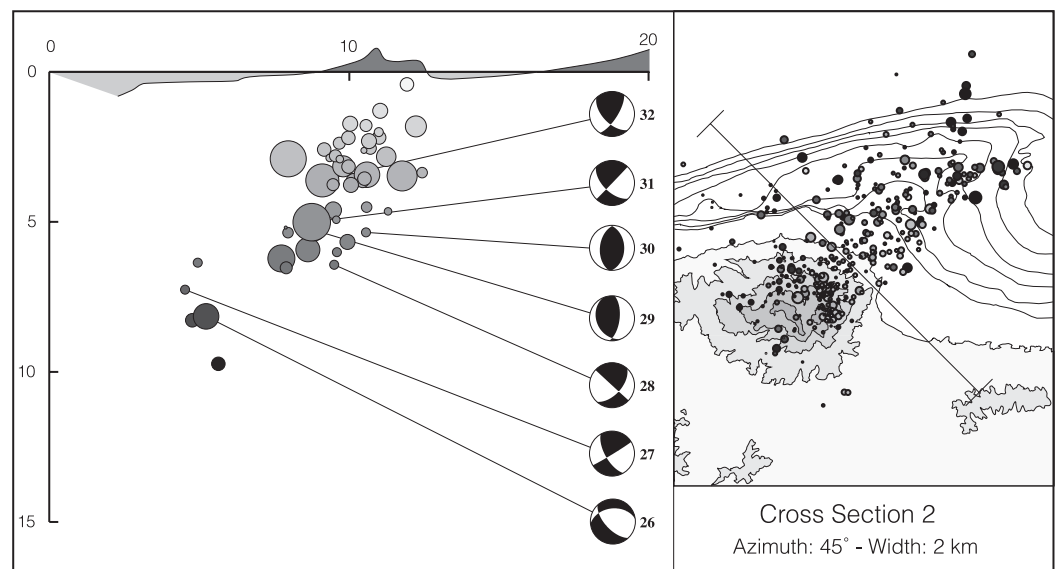

(C)

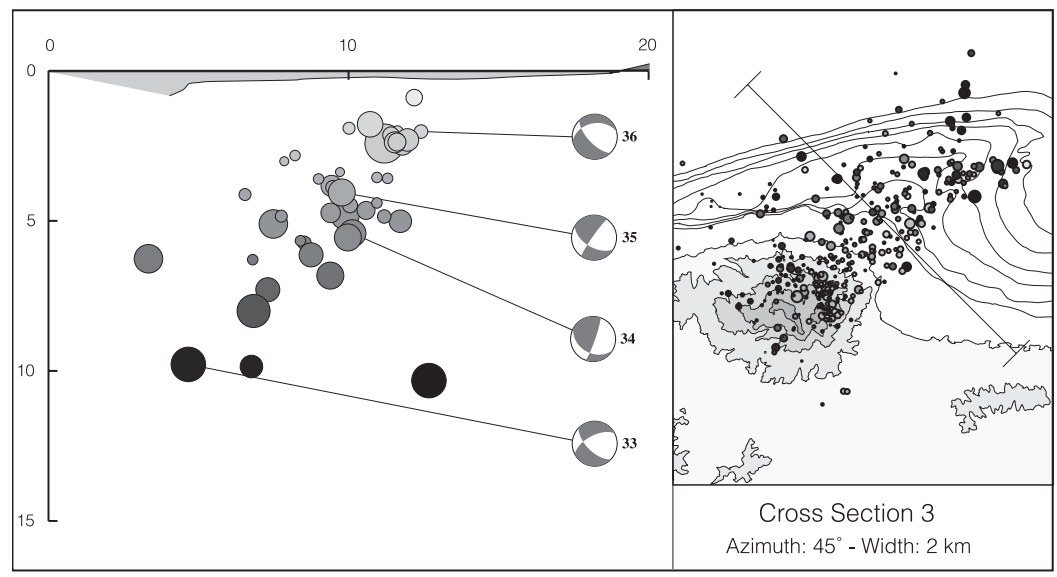

Fig. 7a-c. Vertical cross sections through the hypocenters of the aftershocks along the lines shown in the insets. No vertical exaggeration above sea-level, vertical exaggeration under sea-level by a factor 5 . The focal mechanisms are shown in the lower hemisphere equal area projection. 
of the accelerogram of the mainshock would have occurred on two different, more or less parallel, fault planes. Thus the absence of evident segmentation of the aftershock zone supports the hypothesis of a single fault surface.

Towards SE, the aftershocks are shallower and the aftershock zone ends abruptly along a nearly SW-NE straight line. On the contrary towards NW, the aftershocks are deeper and there is no clear boundary on this side, thus suggesting a NW dipping fault. The relative amount of deep aftershocks seems to be greater towards the northeastern extremity, but this pattern is likely to result from the selection criteria used. We already pointed out that the usual criterion referring to the ratio between the depth and the smallest epicentral distance was not used to select reliable focus parameters. However, the criterion according to which the conditioning factor has to be smaller than a given value acts in a rather similar way, and an inappreciable number of shallow events that occurred at the northeastern extremity of the aftershock area could have been rejected.

At the SW extremity, shallow events form an elongated cluster transverse to the general direction of the seismicity, about $3 \mathrm{~km}$ long, underneath the Chenoua massif. On a crosssection (fig. 7a), this cluster appears to be concentrated around $2.5 \mathrm{~km}$ depth, even if some bias resulting from the presence of a discontinuity at $3 \mathrm{~km}$ depth in the velocity model strengthens the effect. A similar pattern has been observed at the extremities of the main segment of the Spitak source region along which reverse faulting was present (Dorbath et al., 1992). It was then related to transform faulting connecting adjoining segments; in the present case it might be related to shearing at the extremity of the fault.

Three cross-sections, two kilometers wide, orthogonal to the general trend of the aftershock zone are presented in fig. 7a-c. The southern one, fig. $7 \mathrm{a}$, is partly underneath the continent while the two others, figs. $7 \mathrm{~b}$ and $7 \mathrm{c}$, are under the Mediterranean Sea. They clearly show a NW dipping fault plane. The dip angle is about $55^{\circ}$, and it seems to increase from the NE extremity to the SW one. However, the locations of the aftershocks, particularly their depths which are crucial in this purpose, are not well enough con- strained to strongly support the warping of the fault suggested by the cross-sections.

The individual focal mechanisms presented on the cross-sections are produced through the inversion scheme developed by Rivera and Cisternas (1990). The nodal planes are in fairly good agreement with those obtained by eye fitting or by maximum likehood solutions. Only the events with more than 9 reliable polarities were used. A subset of the fault-plane solutions that have been determined is shown in fig. 7a-c. The parameters defining the nodal planes, azimuth, dip and rake according to Aki's convention (Aki and Richards, 1980) are presented in annex for the complete set. A large majority of the mechanisms show reverse faulting, frequently associated with a small left-lateral component, on planes dipping towards NW and striking about SW-NE, thus in agreement with the geometry of the aftershock area and the focal mechanism of the main shock.

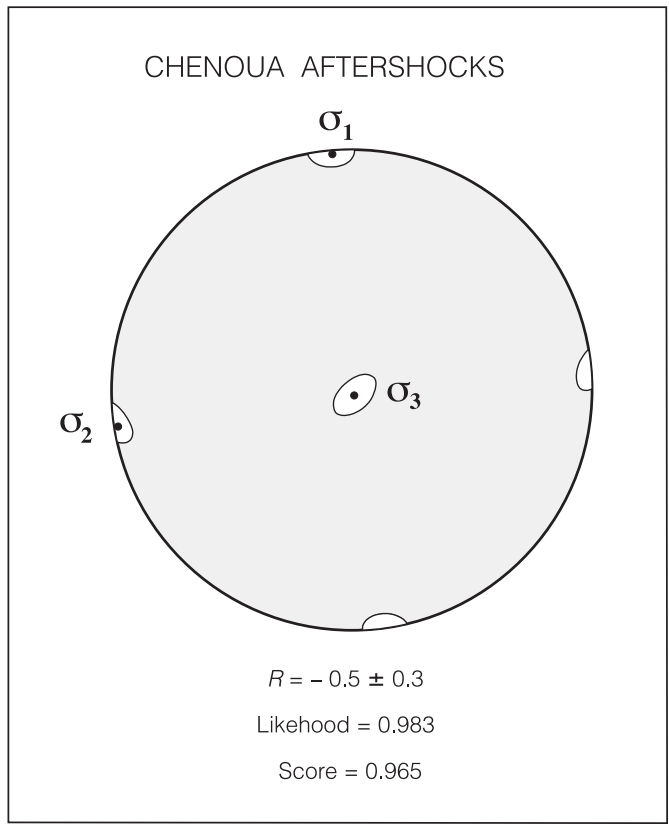

Fig. 8. Orientation of the principal axes of the stress tensor for the Chenoua aftershocks. The ellipses correspond to one standard deviation. Lower hemisphere equal area projection is used. 
Examples of this type of focal solutions are given by the events $\mathrm{n} .10,14,19$ in fig. $7 \mathrm{a}, 27$ and 31 in fig. $7 \mathrm{~b}, 35$ in fig. 7c. Almost pure left-lateral strike-slip faulting occurred also, for examples the events n. 3, 4, 12 on the cross-section 7a, 29 and 30 on the cross-section $7 \mathrm{~b}$. In this case, one of the nodal planes generally strikes SSW-NNE, that is slightly rotated counter-clockwise relatively to the general direction of the aftershock area. Such a variability of the focal solutions is a common feature in aftershock sequences and it should be argued in favour of a heteregeneous stress field, particularly if the $P$ and $T$ axes are confused with the $\sigma_{1}$ and $\sigma_{3}$ axes respectively. On the contrary it has been shown that this apparent inconsistency could be compatible with a unique stress tensor whose parameters, orientation and shape, are obtained by the method proposed by Rivera and Cisternas (1990). Following this method, we performed the inversion of the stress tensor using 62 aftershocks combining 714 polarities. A normalized likehood function of 98.3 per cent was obtained, and 96.5 per cent of the polarities were explained in the hypothesis of a single tensor, thus strongly supporting it. This tensor (fig. 8) has a nearly horizontal NS maximum principal stress $\left(\sigma_{1}\right)$ direction, a vertical minimum principal stress $\left(\sigma_{3}\right)$ direction and a nearly horizontal EW intermediate principal stress $\left(\sigma_{2}\right)$ direction. In this case, the shape factor is $\left(\sigma_{3}-\sigma_{2}\right) /\left(\sigma_{1}-\sigma_{2}\right)$ and its value, -0.5 , is typical of a triaxial compressive regime.

\section{Relocation of the main shock}

The main shock was located by the NEIC, CSEM and ISC at $36^{\circ} 47.28^{\prime} \mathrm{N}, 2^{\circ} 26.88^{\prime} \mathrm{E}$, $36^{\circ} 43.80^{\prime} \mathrm{N}, 2^{\circ} 24.00^{\prime} \mathrm{E}$ and $36^{\circ} 46.80^{\prime} \mathrm{N}, 2^{\circ} 26.40^{\prime}$ E respectively (fig. 9). All these locations are to the north of the zone defined by the aftershock activity and thus they are in conflict with the SWNE sense of propagation of the rupture evidenced by the waveform modellings. We attempted to relocate the main shock with a greater precision by using local and regional data.

No large aftershock occurred when the complete network was in operation, and only an aftershock that occurred on November 22 was recorded by both the local temporary CRAAG network and the regional stations in Spain and Italy. Using the seven Algerian stations that recorded this event, it was located at $36^{\circ} 39.70^{\prime} \mathrm{N}$, $2^{\circ} 28.88^{\prime} \mathrm{E}$. Although the epicenter is far from the nearest stations, this solution is well established by the location routine with a RMS of $0.15 \mathrm{~s}$. The reason is that this event was rather deep, $11.5 \mathrm{~km}$. Nevertheless, it is outside the network and we have to check the reliability of this solution. To estimate the degree of confidence we may attach to the location determined with the Algerian temporary network only, we plotted in fig. 9 the locations of some aftershocks computed with the complete local network, CRAAG plus IPGS stations, and the locations of the same events computed with the Algerian stations alone. As expected, the two locations are close to each other in the case of events inside or close to the network, that is more or less inland, and may be as far as $5 \mathrm{~km}$ away from each other at the northeastern extremity of the aftershocks area. So our «master event» is not the best possible one, since it precisely occurred at that last place and consequently its location may be wrong by $5 \mathrm{~km}$ or so.

We compared the mean of the differences of the arrival times between the master event and the main shock at two sets of relatively distant stations where $P_{n}$ is the first arrival wave: 11 Italian stations constitute the first set and 6 Spanish stations the second. The azimuth of the stations of the first group relatively to the aftershock zone is about the same as the azimuth of the fault plane, while the azimuth of the stations of the second group is nearly orthogonal to the direction of the fault. The epicentral distances are large compared with the extension of the aftershocks zone, so that the differences of the arrival times for the Spanish stations are nearly equal to the difference of the origin times. Subtracting this value to the corresponding one calculated with the Italian stations, it remains only the mean difference of travel times to the Italian stations.

Following this procedure, we found a difference of $-0.9 \mathrm{~s}$. Thus, if $V$ is the local velocity of $P$-wave and $i$ is the take-off angle, the epicenter of the main shock is at a distance $0.9 \times V / \sin (i)$ from the epicenter of the master event, in the SW direction. With $V=6.0 \mathrm{~km} / \mathrm{s}$ and $i=45^{\circ}$, this distance is about $7.5 \mathrm{~km}$, and the epicenter of 


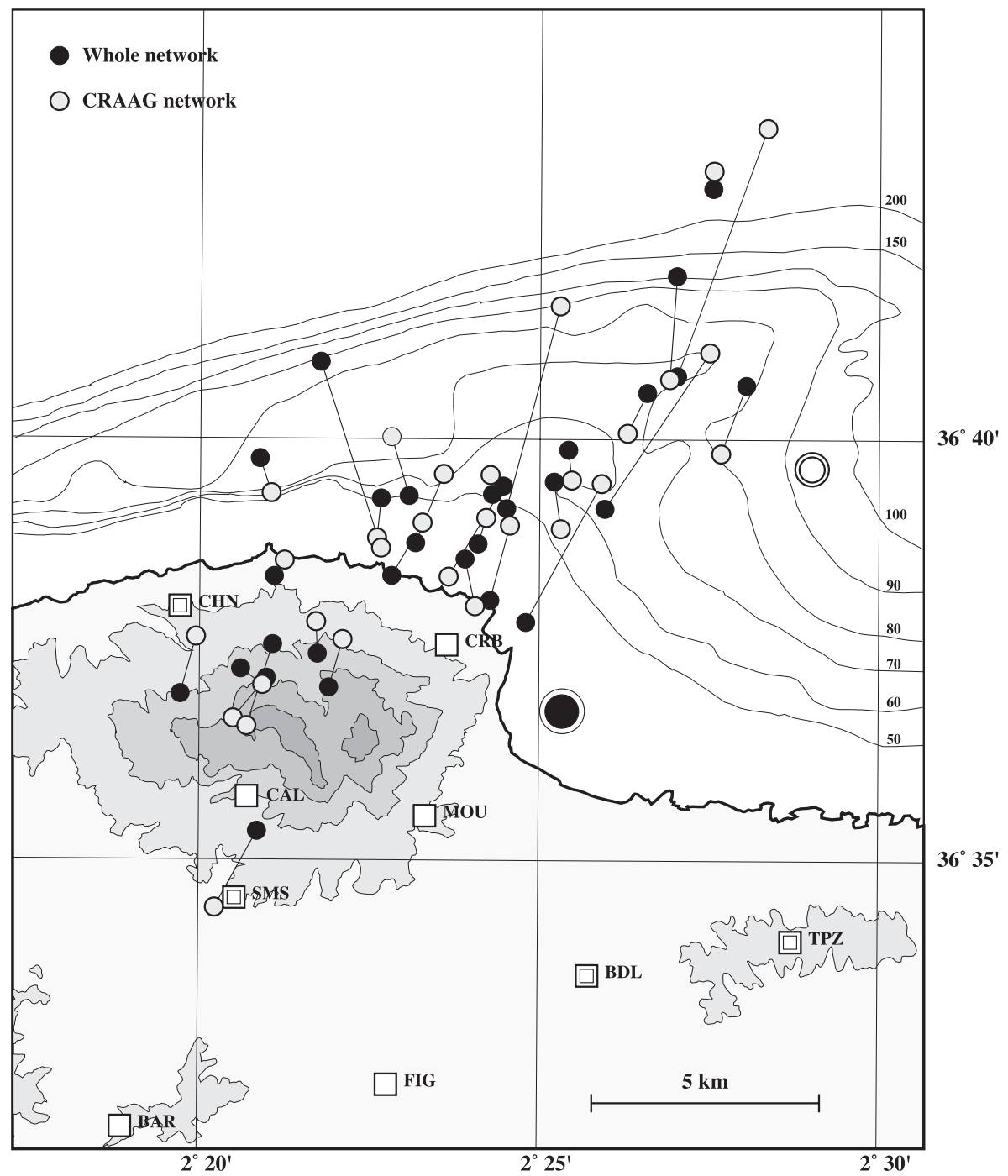

Fig. 9. Comparison of the locations calculated with the complete network (CRAAG + IPGS stations) and the locations calculated with the CRAAG stations only. Large open circle: epicenter of the master event; large solid circle: epicenter of the main shock.

the main shock is located in the southern part of the aftershock zone (fig. 9) and slightly outside it. This last feature directly results from the position of the master event, outside the aftershocks cloud as well. The uncertainties and the hypothesis make this result poorly constrained by itself, but it streng- thens the result suggested through the inversion of teleseismic waves and the modelisation of the accelerogram, namely that the nucleation point of the main shock was at the southeastern edge of the fault and that the rupture propagated from SW towards NE. 


\section{Discussion and conclusions}

Different methods have been applied to produce a detailed description of the Chenoua earthquake, although it was not a large event, and the agreement between the pictures inferred from these different approaches is quite good. Some discrepancies exist, but they are not significant when the error bars are taken into account.

Though some complexities could appear, the general picture shows a rather simple feature, such as could be expected from an earthquake of magnitude $M_{w}=5.9$. The Chenoua earthquake occurred likely on a single surface of rupture, plane or nearly plane, striking about $240^{\circ}$ and dipping about $55^{\circ}$ to the NW. The main shock resulted from the combination of two sub-events, which is the degree of complexity that the data are able to resolve, and the rupture propagated from SW towards NE. From the aftershock study, the fault is 13 to $15 \mathrm{~km}$ long and 10 to12 $\mathrm{km}$ wide along the dip. With these values, an elastic modulus $\mu=3.310^{10} \mathrm{Nm}^{-2}$ and the seismic moment coming from the modelisation of body waves, $8.2 \times 10^{17} \mathrm{Nm}$, we obtain a displacement of 15 to $20 \mathrm{~cm}$. This value is in the range of what is generally expected for an event with a magnitude 5.9. For example, the displacement was less than $20 \mathrm{~cm}$ during the 1986 Kalamata earthquake $\left(M_{S}=5.9\right.$, Lyon-Caen et al., 1988) and about 40 $\mathrm{cm}$ during 1983 earthquake of Guinea $\left(M_{S}=6.3\right.$, Dorbath et al., 1985). The rupture did not reach the surface, at least along the segment observed within the continent.

Soon after the earthquake, a field survey was conducted to observe surface deformations (Meghraoui, 1992). Several hundreds of meters of complex and discontinuous surface cracks and fissures network was discovered on the southern side of Mount Chenoua, southward of the main thrust which was not reactivated. Most of them are striking about E-W with a few NESW en échelon left-lateral cracks and localized right-lateral ones. Vertical displacements are only noticeable at the western extremity of the fissures network where they reach about $10 \mathrm{~cm}$. The southern block was uplifted relatively to the northern one, the opposite of the expected movement along the north dipping main reverse fault which bounds the Chenoua Mountain to the south. On the other hand, these surface ruptures are parallel to the nearly vertical beds of folded and flexured Neogene formations. These observations lead us to interpret the surface breaks as secondary effects resulting of slipping on bedding planes due to the intense shaking close to the epicenter. This interpretation is supported by the two seismological results. First, there is no aftershock activity along the observed craks, although the area was properly covered by the seismological stations and, second, the attempts made to modelize the body-waves by a single point source, or one of the two sub-events, located there and striking E-W failed to fit the observations.

The earthquake took place on a fault that borders the Chenoua massif to the east. The past activity of this fault is evidenced by the topographic pattern of the flank of the massif which shows linear and parallel contour lines, and by the bathimetry. The bathimetric curves clearly indicate the presence of a fold, whose axis trends about $60^{\circ} \mathrm{N}$ (fig. 6). The fold is asymmetrical, with its steepest side to the SE, a figure compatible with the presence of a NW dipping fault running along its southeastern flank. Thus, the Chenoua massif is located within the wedge formed by the intersection of two faults, one to the south of the massif and one to the east, which form an angle of about $150^{\circ}$. Since the movement on both faults has a dominant component of inverse dip slip, there is a large concentration of the deformation in the wedge. On the other hand, these two faults are rather steep, $50^{\circ}$ to $55^{\circ}$ from surface observations for the southern fault (Meghraoui, 1992) and from the cross-sections in fig. 7a-c, so that the NS compression results in large vertical motion. The consequence of the two effects, the existence of a wedge and the steepness of the faults, is the formation of a high relief. 


\section{Appendix}

Focal mechanisms obtained through the joint inversion of the stress-tensor and focal solutions. Solid circle denotes compression; open circle denotes dilatation. Lower hemisphere equal area projection.
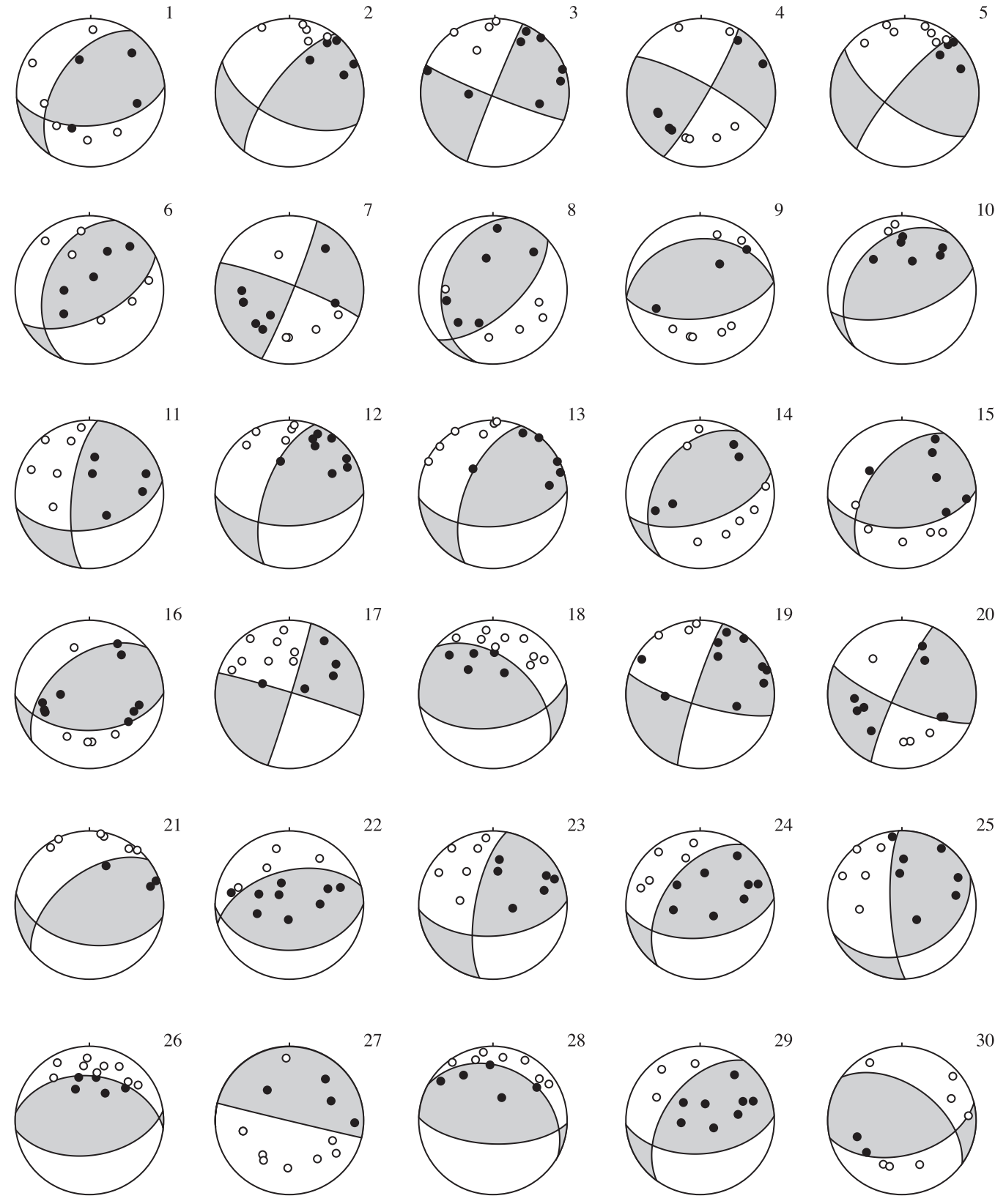


\section{Appendix (continued)}
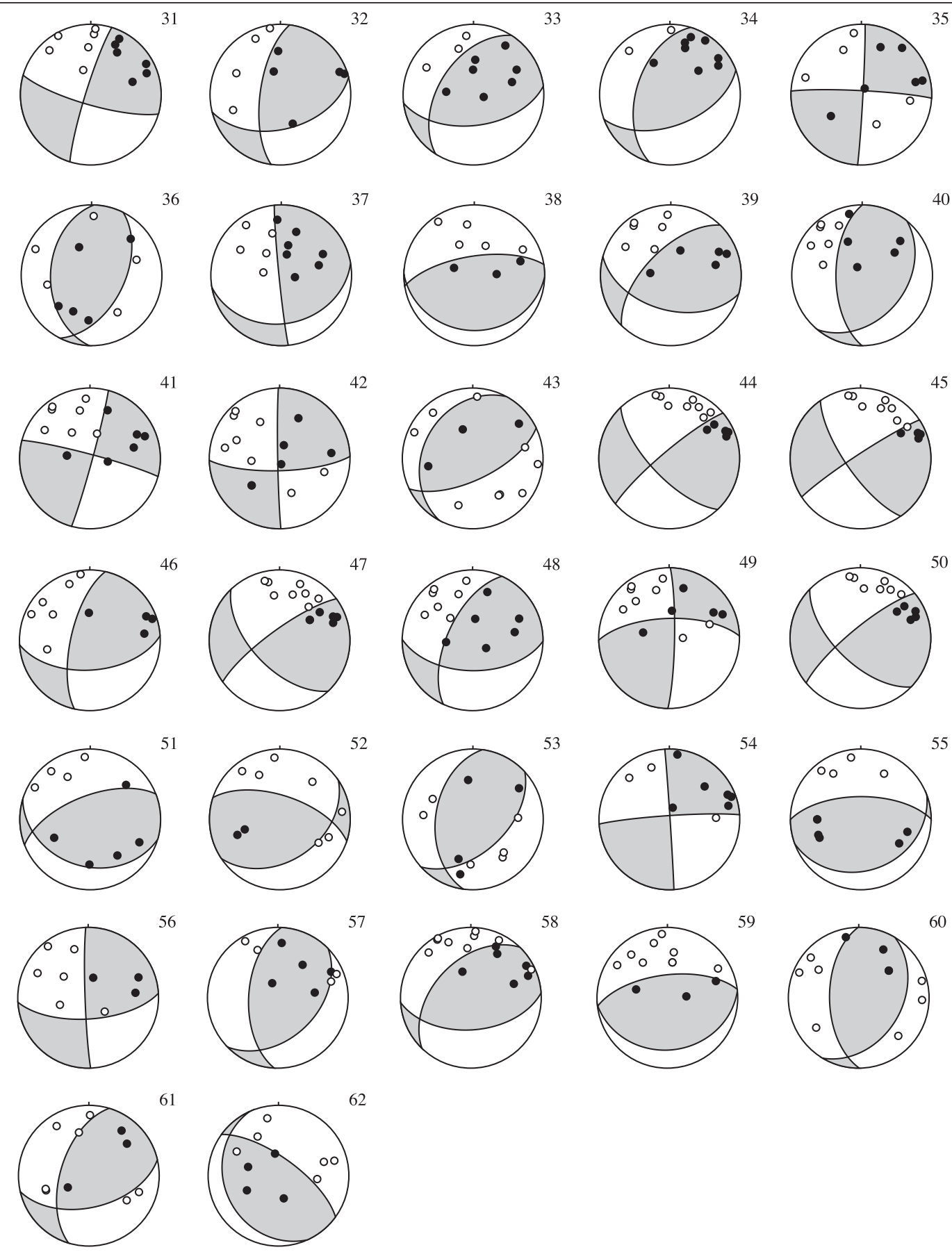


\section{REFERENCES}

AKI, K. and P.G. RICHARDS (1980): Quantitative Seismology: Theory and Methods (W.H. Freeman \& Co., San Francisco), vol. 1, pp. 557.

Ambraseys, N. and J. Vogt (1988): Material for the investigation of the seismicity of the region of Algiers, Eur. Earthquake Eng., 3, 16-29.

ANDERSON, H. and J. JACKSON (1987): Active tectonics of the Adriatic region, Geopys. J. R. Astron. Soc., 91, 937-983

ARMIJO, R., E. CAREY and A. CISTERNAS (1982): The inverse problem in microtectonics and the separation of tectonic phases, Tectonophysics, 82, 145-160.

Avouac, J.-P., B. MeYER and P. TAPPONNIER (1992): On the growth of normal faults and the existence of flats and ramps along the El-Asnam active fold and thrust system, Tectonics, 11, 1-11.

Belhai, D., O. Merle and A. SaAdalah (1990): Transpression dextre à l'Éocène supérieur dans la chaîne des Maghrébides (massif du Chenoua, Algérie), C.R. Acad. Sci. Paris, 310, sér. II, 795-800.

Bezzeghoud, M., J. Dimitrov, J.-C. RuegG and K. LAMMALI (1995): Faulting mechanism of the 1954 and 1980 earthquakes from vertical movements modelling, Tectonophysics, 249, 249-266.

Bounif, A. and C. Dorbath (1998): Three dimensional velocity structure and relocated aftershocks for the 1985 Constantine, Algeria $\left(M_{s}=5.9\right)$ earthquake, Ann. Geofis., 41 (1), 93-104.

Bounif, A., H. HAESSLER and M. MEgHRAOUI (1987): The Constantine (Northeast-Algeria) earthquake of October 27, 1985: surface ruptures and aftershocks study, Earth Planet. Sci. Lett., 85, 451-460.

Chase, C.G. (1978): Plate kinematics: the Americas, East Africa and the rest of the world, Earth Planet. Sci. Lett., 85, 451-460.

Cisternas, A., J. Dorel and R. Gaulon (1982): Models of complex source of the El-Asnam earthquake, Bull. Seismol. Soc. Am., 72, 2245-2266.

Deschamps, A., Y. GAUdEMER and A. Cisternas (1982): The El-Asnam earthquake of October 10, 1980: multiplesource mechanism determined from long-period records, Bull. Seismol. Soc. Am., 72, 1111-1128.

Deschamps, A., M. BezZEGHoud and A. Bounif (1991): Seismological study of the Constantine (Algeria) earthquake (27 October 1985), in Seismicity, Seismotectonics and Seismic Risk of the Ibero-Maghrebian Region, edited by J. MEZCUA and A. UDIASEDS (Instituto Geografico Nacional, Madrid), Monogr. n. 8, 163-173.

DEWEY, J.W. (1991): The 1954 and 1980 Algerian earthquakes: implications for the characteristic displacement model of fault behavior, Bull. Seismol. Soc. Am., 81, 446-467.

Dorbath, L., C. Dorbath, R. Gaulon, T. George, P. Mourgue, M. Ramdani, B. Robineau and B. TADILI (1985): Seismotectonics of the Guinean earthquake of December 22, 1983, Geophys. Res. Lett., 11, 971-974.

Dorbath, L., C. Dorbath, L. Rivera, A. Fuenzalida,
A. Cisternas, R. Tatevossian, J. Aptekman and S. AREFIEV (1992): Geometry, segmentation and stress regime of the Spitak (Armenia) earthquake from the analysis of the aftershock sequence, Geophys. J. Int., 108, 309-328.

GLANGEAUD, L. (1932): Étude géologique de la province d'Alger, Bull. Serv. Carte Géol. Algérie, sér. II, 8.

Hartzell, S., G.A. Frazier and J. Brune (1978): Earthquake modeling in a homogeneous half-space, Bull. Seismol. Soc. Am., 68, 301-316.

JOHNSON, L.R. (1974): Green's function for Lamb's problem, Geophys. J. R. Astron. Soc., 37, 99-131.

KLEIN, F.W. (1978): Hypocenter location programm HYPOINVERSE, Open-file Rep. 78-694 (US Geological Survey, Boulder, CO, U.S.A).

Lyon-Caen, H., R. Armijo, J. Drakopoulos, J. BasKOUTASS, N. DELIBASSIS, R. GAULON, V. KOUSKOUNA, J. LATOUSSAKIS, K. MAKROPOULOS, P. PAPADIMITRIOU, D. Papanastassiou and G. Pedotti (1988): The Kalamata (South Peloponneus) earthquake: detailed study of a normal fault, evidences for east-west extension in the Hellenic Arc, J. Geophys. Res., 93, 14,967-15,000.

MC CAFFREY, R. and G. ABERS (1988): SYN3: a program for inversion of teleseismic body wave forms on microcomputers, Air Force Geophysics Laboratory Technical report AFGL-TR-88-0099 (Hanscomb Air Force Base, MA), pp. 50.

MeghraOUI, M. (1988): Géologie des zones sismiques du Nord de l'Algérie: paléosismologie, tectonique active et synthèse sismotectonique, Thèse Univ. Paris-Sud Orsay, pp. 350.

Meghraoui, M. (1992): Blind reverse faultings ystem associated with the Mont Chenoua-Tipaza earthquake of 29 October1989 (North-Central Algeria), Terra Nova, 3, 84-93.

Meghraoui, M., A. Cisternas and H. Philip (1986): Seismotectonics of the lower Chelif basin: structural background of the El-Asnam (Algeria) earthquake, Tectonics, 5, 809-836.

NABELEK, J.L. (1984): Determination of earthquake source parameters from inversion of body waves, $P h$. D. Thesis, M.I.T.

OUYED, M. (1981): Le tremblement de terre d'El Asnam du 10 Octobre - Etude des répliques, Thèse de 3e Cycle, Université Scient. et Méd. de Grenoble, France.

Ouyed, M., M. Meghraoui, A. Cisternas, A. Deschamps, J. DOREL, J. FRECHET, R. GAULON, D. HATZFELD and H. HILIP (1981):The El-Asnam earthquake of October 10, 1980: seismotectonics, Nature, 292, 26-31.

OUYED, M., G. YIELDING, D. HATZFELD and G.C.P. KING (1983): An aftershock study of the El-Asnam (Algeria) earthquake of October 10,1980, Geophys. J.R. Astron. Soc., 73, 605-639.

PhILIP, H. and M. MeghraOUI (1983): Structural analysis and interpretation of the suface deformations of the El-Asnam earthquake of October 10, 1980, Tectonics, 2, 17-49.

RIVERA, L. and A. CISTERNAS (1990): Stress tensor and fault plane solutions for a population of earthquakes, Bull. Seismol. Soc. Am., 80, 600-614. 
Rothe, J.P. (1950): Les séismes de Kherrata et la sismicité de l'Algérie, Bull. Ser. Carte Geol. Algérie, 3, 1-40.

RuEGG, J.-C., M. KASSER, A. TARANTOLA, J.-C. LePINE and B. Chouikrat (1982): Deformation associated with the El-Asnam earthquake of October 10,1980: geodetic determination of vertical and horizontal movements, Bull. Seismol. Soc. Am., 72, 2227-2244.

YiELDING, G., M. OUYED, G.C.P. KING and D. HATZFELD (1989): Active tectonics of the region of the Algerian
Atlas Mountains - evidence from aftershocks of the ElAsnam earthquake, Geophys. J. Int., 99, 761-788.

Yelles-ChaOUCHE, A. (1991): Coastal Algerian earthquakes: a potential risk of tsunamis in Western Mediterranean? Preliminary investigation, Science of Tsunami Hazards, 9 (1), 47-54.

(received November 26, 2002; accepted March 26, 2003) 